\title{
Salt Tolerance and Cation Interaction in Alkali Sacaton at Germination ${ }^{1}$
}

\section{S. Z. HYDER AND SHAMSA YASMIN2}

Department of Botany, University of Sind, Jamshoro, West Pakistan.

\section{Highlight}

Salt tolerance and cation interaction in alkali sacaton (Sporobolus airoides Torr.) was studied during the germination stage. Germination was inhibited at a concentration of 275 meq/liter of sodium chloride. Mannitol and other salts at iso-osmotic pressure restricted germination in the following decreasing order: $\mathrm{MgCl}_{2}, \mathrm{KCl}, \mathrm{CaCl}_{2}, \mathrm{NaCl}$, and mannitol. Inhibitory effects of magnesium on germination were partially counteracted by calcium and sodium. Greater recovery in germination was noted by addition of calcium than sodium in seeds previously treated with a high concentration of magnesium chloride. The role of sodium and calcium in counteracting magnesium effects has been discussed. It is also concluded that specific effects of salts are more important than osmotic effects on the seed germination of this species.

Cultivation of salt tolerant forage plants which can grow under natural rainfall is profitable where land is highly saline and adequate water for leaching down the salt is not available (Malcolm, 1969). This approach is one utilization rather than reclamation of saline soils. Vast areas of land with low rainfall and high salinity are found throughout West Pakistan. Neither crops nor good quality grasses can grow on such lands. In the southern region of West Pakistan this problem is more acute because of fodder shortage. In order to make the best use of such land, a search is being made for exotic species which can thrive and produce fodder under our local conditions.

Alkali sacaton (Sporobolus airoides Torr.) is an important forage plant of southwestern United States. It has a reputation of being highly salt tolerant (Hayward and Bernstein, 1958), and is particularly used for soil stabilization (Aldon, 1969). The climate of southwestern

\footnotetext{
${ }^{1}$ The rescarch reported was financed in part by a grant made by the United States Department of Agriculture under PL-480. Manuscript received September 2, 1971.

2 Grateful acknowledgement is accorded to Dr. Wesley Keller, Utah Statc University, Logan, Utah, for providing the seeds and Dr. Alma M. Wilson of Washington State University for making helpful criticism of the manuscript.
}

United States is similar to that of the southern region of West Pakistan. For these reasons this plant was included in our preliminary studies carried out for determining salt tolerance under laboratory conditions. The present report describes the results of this study.

\section{Materials and Methods}

Seeds of alkali sacaton were obtained from the Crops Research Laboratory, Utah State University, Logan, Utah. Healthy seeds were selected for experiments and sterilized with $0.1 \% \mathrm{HgCl}_{2}$ solution for one minute. These seeds were soaked in distilled water for 18 hours prior to imposing treatments. Seeds were germinated in water culture in a laboratory at room temperature. The temperature ranged between $90 \mathrm{~F}$ to $100 \mathrm{~F}$ during the day and 65 to $75 \mathrm{~F}$ during the night. Small polythene cups of $200 \mathrm{ml}$ capacity were used as culture vessels. Polythene nets were used to support the seeds in the vessels. These nets were suspended over the treatment solutions in the culture vessels and 50 seeds were placed on the nets in each vessel. The seeds were covered with watch glass to keep the atmosphere humid.

The saline treatments were imposed by adding various salts to the distilled water in increasing concentration. To obtain osmotic pres- sure equivalent to $1 \mathrm{~atm} 25 \mathrm{meq}$ of $\mathrm{NaCl}$ and $\mathrm{KCl}$, and 32 meq of $\mathrm{CaCl}_{2}$ and $\mathrm{MgCl}_{2}$ were dissolved in one litre of distilled water. Higher osmotic pressures of these solutions were calculated on the same basis. The osmotic pressure of mannitol was adjusted according to the technique of Uhvits (1946). Germination in distilled water served as the control.

Observations were recorded by counting the germinated seeds. To begin with, germination was recorded every day starting from the 3rd to 9 th day after commencement of the experiment and then on alternate days till the conclusion of the experiment. A seed was considered to be germinated when both roots and coleoptile had attained the length of $3 \mathrm{~mm}$.

Germinated seeds were discarded after counting. The experiments were continued for 12 to 16 days, and the treatments were replicated 4 times.

\section{Results \\ Effects of Various $\mathrm{NaCl}$ Concentrations}

Concentrations of $\mathrm{NaCl}$ used for imposing salinity were $25,75,125$, $225,275,325 \mathrm{meq} / \mathrm{liter}$. Figure 1 shows that $125 \mathrm{meq} /$ liter of $\mathrm{NaCl}$ inhibited germination more than $50 \%$, with a greater depression at higher concentrations of $\mathrm{NaCl}$. Germination of seeds continued at $275 \mathrm{meq} /$ liter of $\mathrm{NaCl}$, but virtually stopped at the highest concentration of $\mathrm{NaCl}$ used.

\section{Effects of Different Salts}

$\mathrm{NaCl}, \mathrm{KCl}, \mathrm{CaCl}_{2}$, and $\mathrm{Mgcl}_{2}$ at 1 and 2 atm were compared for their effects on seed germination. Figure 2 shows that $\mathrm{NaCl}$ at 1 atm had little inhibitory effect on seed germination, but at 2 atm some inhibition in germination was noted. The other salts depressed germination even at $1 \mathrm{~atm}$ and the effects became more pronounced at 2 atm. The depression effect in decreasing order was $\mathrm{MgCl}_{2}, \mathrm{KCl}, \mathrm{CaCl}_{2}$, and $\mathrm{NaCl}$. 


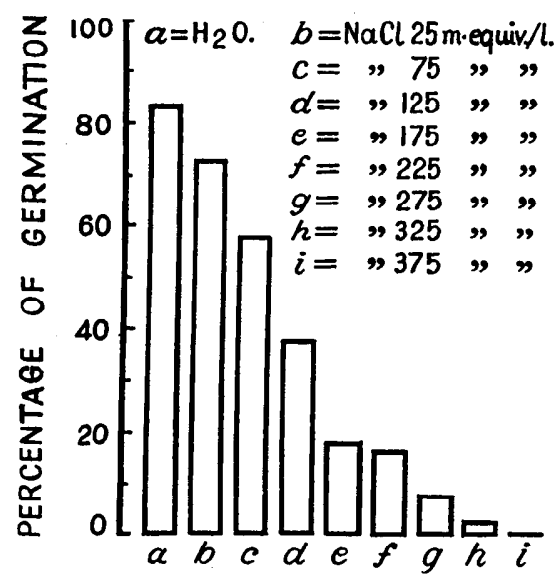

Fig. 1. Effects of $\mathrm{NaCl}(0$ to $375 \mathrm{meq} / \mathrm{liter})$ on sced germination.

\section{Comparison of Effects of Salts} and Mannitol

$\mathrm{NaCl}, \mathrm{KCl}, \mathrm{CaCl}_{2} \mathrm{MgCl}_{2}$, and mannitol at $3 \mathrm{~atm}$ were used to distinguish between osmotic and non-osmotic effects on germination. Mannitol at $3 \mathrm{~atm}$ depressed germination only slightly but other salts depressed germination significantly at this level of salinity (Fig. 3). The depression of germination by the salts was in the same order as in Figure 2.

\section{Interaction of $\mathrm{Na}^{+}$and $\mathbf{M g}^{++}$}

The interaction of $\mathrm{NaCl}$ and $\mathrm{MgCl}_{2}$ was studied because at isoosmotic concentrations $\mathrm{NaCl}$ was much less inhibitory than $\mathrm{MgCl}_{2}$. $\mathrm{NaCl}$ at 10, 20, and $25 \mathrm{meq} /$ liter was added to a solution containing

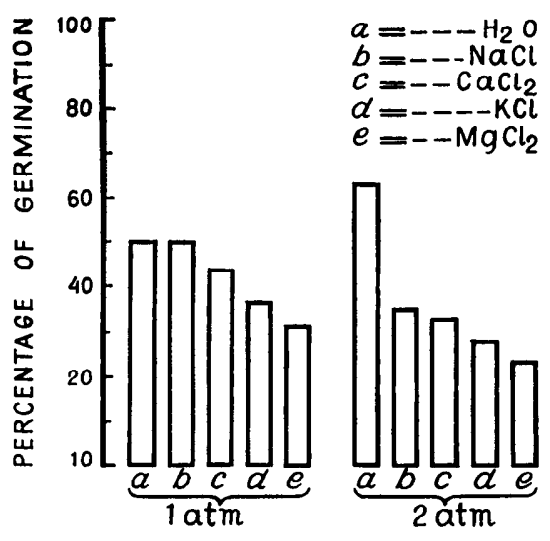

FIG. 2. Effects of $\mathrm{NaCl}, \mathrm{KCl}, \mathrm{CaCl}_{2}$ \& $\mathrm{MgCl}_{2}$ at 1 and 2 atmospheres on seed germination.

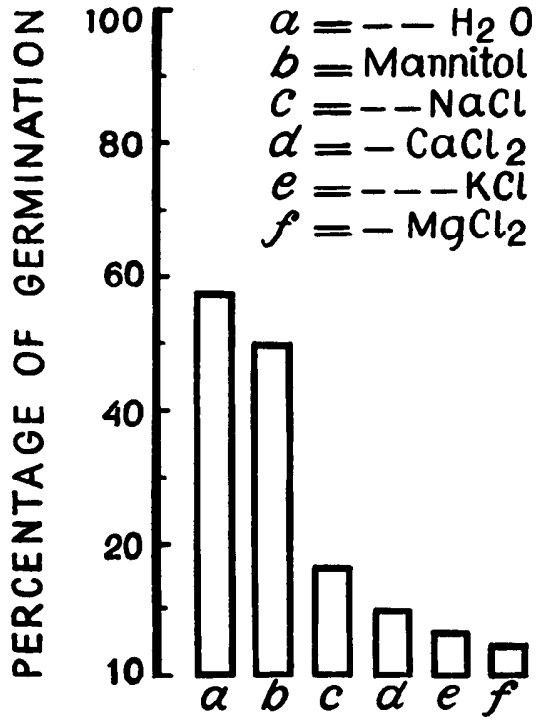

Fig. 3. Effects of mannitol, $\mathrm{NaCl}, \mathrm{KCl}$, $\mathrm{CaCl}_{2}$, and $\mathrm{MgCl}_{2}$ at 3 atm on seed germination.

$\mathrm{MgCl}_{2}$ at $3 \mathrm{~atm}$. For comparison, $\mathrm{NaCl}$ at 4 atm was also tested. $\mathrm{MgCl}_{2}$ at $3 \mathrm{~atm}$ greatly depressed germination (Fig. 4). The inhibitory effects of $\mathrm{Mg}^{++}$were partly neutralized by adding various concentrations of $\mathrm{NaCl}$.

\section{Interaction of $\mathrm{Na}^{+}, \mathrm{K}^{+}$, and $\mathrm{Ca}^{++}$ with $\mathbf{M g}^{++}$}

$\mathrm{NaCl}, \mathrm{KCl}$, and $\mathrm{CaCl}_{2}$ at $20 \mathrm{meq} /$ liter with $\mathrm{MgCl}_{2}$ at $3 \mathrm{~atm}$ were studied in order to determine if these salts also counteract the inhibitory effects of $\mathrm{Mg}^{++}$on germination. The inhibitory effects of $\mathrm{Mg}^{++}$ were counteracted more by addition of $\mathrm{CaCl}_{2}$ than $\mathrm{NaCl}$; addition of $\mathrm{KCl}$, however, had little effect (Fig. 5).

Recovery in Germination on Addition of $\mathrm{Na}^{+}$and $\mathrm{Ca}^{++}$

After pretreatment of seeds in 3 atm $\mathrm{MgCl}_{2}$ for 24 or 48 hours, 20 mcq/liter of $\mathrm{CaCl}_{2}$ or $\mathrm{NaCl}$ was added to the $\mathrm{MgCl}_{2}$ solution to determine the relative effectiveness of $\mathrm{NaCl}$ and $\mathrm{CaCl}_{2}$ in counteracting the inhibitory effects of $\mathrm{MgCl}_{2}$. The pcrcentage of recovery was greater in the presence of $\mathrm{Ca}^{++}$than $\mathrm{Na}^{+}$in the 24 hour pretreatment period (Fig. 6). A similar trend, though less pronounced, was also

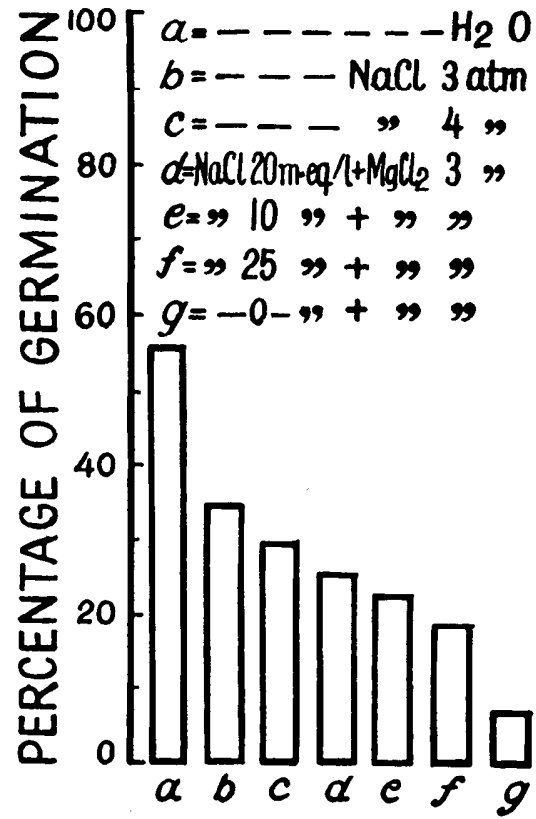

Fig. 4. Interaction of $\mathrm{MgCl}$ (3 atm) and $\mathrm{NaCl}(10,20$, and $25 \mathrm{meq} /$ liter $)$ on seed germination.

noted in the 48-hour pretreatment period.

\section{Discussion}

There is very scanty information on the salt tolerance of alkali sacaton. However, Richards et al. (1954) have shown that this species grows better between $0.3 \%$ and $0.5 \%$ soil salinity than at higher concentrations. In the present investigation the germination of seed continued at $275 \mathrm{meq} /$ liter of $\mathrm{NaCl}$, indicating a good salt tolerance of this species, at least during germination. Salt relations of seed during germination are as important as during later growth stages. In the present study, high concentrations of salt in the medium restricted germination. Ionic species differed in their inhibitory effects on germination. For example, there was greater reduction in germination in chlorides of $\mathrm{Mg}^{++}$and $\mathrm{K}^{+}$ than $\mathrm{Na}^{+}$and $\mathrm{Ca}^{++}$at equal osmotic concentrations (Fig. 2).

Interionic influences on the uptake process have been studied in the past but their effects on seed germination have not been thoroughly investigated. With mea- 


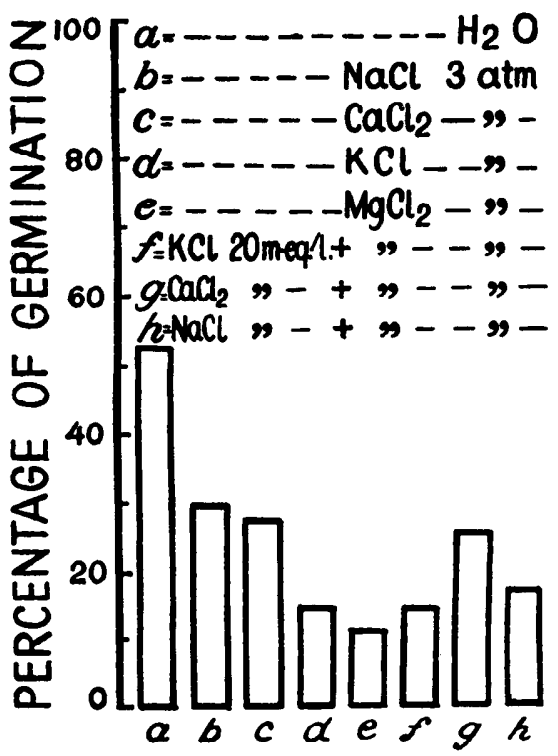

Fig. 5. Interaction of $\mathrm{MgCl}(3 \mathrm{~atm})$ and $\mathrm{NaCl}, \mathrm{KCl}$, and $\mathrm{CaCl}_{2}$ (20 meq/liter) on seed germination.

ger data in hand it is difficult to arrive at definite conclusions on the cause of reduced germination in $\mathrm{MgCl}_{2}$. It is likely that the ionic balance of seeds in solution of high MgCl concentration was drastically changed. $\mathrm{Mg}^{++}$may have a direct effect on seed metabolism and thus restrict the germination process. In studying the interaction of $\mathrm{MgCl}_{2}$ with other ions it was found that addition of $\mathrm{Ca}^{++}$and $\mathrm{N}^{+}$counteracted the deleterious effects of $\mathrm{Mg}^{++}$.

Effects of $\mathrm{Na}^{+}$in counteracting $\mathrm{Mg}^{++}$inhibition of germination are surprising but the possibility of its nutritive role can not be ruled out since its essentiality in some halophytes such as Atriplex vesicaria has been established (Brownell, 1965). The interaction of $\mathrm{Ca}^{++}$and $\mathrm{Mg}^{++}$is well known. Both are divalent and may compete for similar absorption sites. Greater recovery in germination on addition of $\mathrm{Ca}^{++}$than $\mathrm{Na}^{+}$(Fig. 6) may

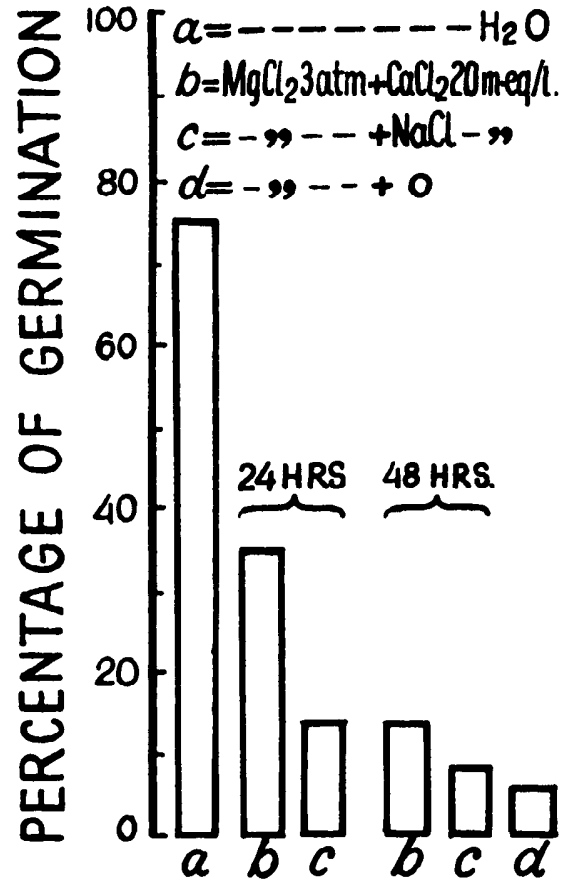

FIG. 6. Recovery in germination on addition of $\mathrm{NaCl}, \mathrm{CaCl}_{2}(20 \mathrm{meq} / \mathrm{liter})$ after 24 hours, and 48 hours of pretreatment with $\mathrm{MgCl}_{2}$ (3 atm).

be due to effects of $\mathrm{Ca}^{++}$on seed membranes. Calcium is important in maintaining the structure of the protoplasm and semipermeability of the membranes (Fisher, 1966). Epstein (1961) has shown that $\mathrm{Ca}^{++}$ is essential for maintaining the integrity of selective ion transport mechanisms. High $\mathrm{MgCl}_{2}$ may replace the endogenous $\mathrm{Ca}^{++}$from seeds and consequently cause disorganization of protoplasm and depression of germination.

Germination in a saline environment is affected by osmotic and specific ion effects (Uhvits, 1946). Knipe (1968) reported that germination of alkali sacaton was severely restricted by moisture tension greater than 1 atm. In the present study the major factor re- stricting germination was the specific effect of salts; germination was more severely depressed in various salt solutions than in the iso-osmotic concentration of mannitol.

The conclusion which can be drawn from the present study is that the establishment of this grass in the field will depend on the salt concentration and ionic composition of the soil. Soil rich in $\mathrm{Mg}^{++}$and low in $\mathrm{Ca}^{++}$will not favor germination.

\section{Literature Cited}

Aldon, Earl F. 1969. Alkali sacaton seedling survival and early growth under temperature and moisture stress. U.S. Forest Serv., Rocky Mt. Forest and Range Exp. Sta. Res. Note RM 136. 4 p.

Browneld, P. F. 1965. Sodium as an essential micronutrient element for a higher plant (Atriplex vesicaria). Plant Physiol. 40:460-168.

EPSTEIN, E. 1961. The essential role of calcium in selective cation transport by plant cell. Plant Physiol. 36: 437-444.

FISHER, H. IONEWIRKUNG. 1966. Encyclopaedia of Plant Physiology II 706-746.

Hayward, H. E., and L. Bernstein. 1958. Plant growth relationship on salt affected soils. Bot. Rev. 24:484635.

KNIPE, O. D. 1968. Effects of moisture stress on germination of alkali sacaton, galleta, and blue grama. J. Range Manage. 21:3-4.

Malcolm, C. V. 1969. Use of halophytes for forage production on saline wastelands. The J. Aust. Inst. Agr. Sci. 35:38-49.

Richards, L. A., (Editor). 1954. Diagnosis and improvement of saline and alkali soils. U.S. Dep. Agr. Agr. Handbook 60. $160 \mathrm{p}$.

UHvits, R. 1946. Effects of osmotic pressure on water absorption and germination of alfafa seed. Am. J. Bot. 33:278-285.

\section{Specialists in Quality NATIVE GRASSES}

Wheatgrasses • Bluestems • Gramas • Switchgrasses • Lovegrasses • Buffalo • and Many Others

We grow, harvest, process these seeds

Your Inquiries

Appreciated 